\title{
PREVENTIVE PHARMACOTHERAPY OF TYPE 2 DIABETES MELLITUS IN PATIENTS WITH EARLY CARBOHYDRATE METABOLISM DISORDERS: LONG-TERM EFFICACY AND CLINICAL OUTCOMES
}

Boeva W1凶, Zavyalov AN²

Federal Clinical Center of High Medical Technologies, FMBA, Khimki, Moscow region, Russia

2 Pirogov Russian National Research Medical University, Moscow, Russia

Prevention of type 2 diabetes mellitus (T2DM) in prediabetic patients is a pressing concern due to its increasing prevalence. The aim of this study was to evaluate the efficacy of preventive pharmacotherapy in delaying progression of incident impaired glucose tolerance (IGT) and impaired fasting glycemia (IFG) to T2DM. The participants of the study (1,136 subjects) found healthy by a regular annual checkup underwent repeat screening for T2DM. Blood samples were processed following the guidelines for good preanalytical sample preparation. Patents with incident IGT/IFG were prescribed medication therapy with metformin or/and acarbose. The rate of IGT/IFG conversion to T2DM was evaluated in years 3 and 10 of observation. Carbohydrate metabolism disorders were detected in $18.5 \%$ ( $n=210$ ) of the re-screened patients: $5.0 \%$ had T2DM, 5.5\% had IGT, 8.0\% had IFG. Patients with incident T2DM were prescribed blood sugar lowering therapy and they were excluded from further analysis. Patients with IGT/IFG $(n=151)$ were given recommendations on lifestyle modification and prescribed metformin $(77 \%)$ or a combination of metformin and acarbose (23\%). Three years after the start of observation, the rate of conversion to T2DM was $6.8 \%$ in patients undergoing monotherapy with metformin and $11.4 \%$ in patients undergoing combination therapy with metformin and acarbose. After the active follow-up phase was over, the majority of the patients $(n=85)$ decided to discontinue preventive therapy without consulting their physicians. Ten years after the active follow-up phase, the rate of NGT/IFG conversion to T2DM was 38.8\% in patients who had discontinued their treatment and $0 \%$ in patients still taking metformin ( $<<0.01$ ). Long-term therapy with metformin prevented progression to T2DM in the long run in $83.3 \%(p<0.05)$.

Keywords: type 2 diabetes mellitus, impaired fasting glucose, impaired glucose tolerance, screening, metformin, acarbose, prevention, fasting plasma glucose

Author contribution: Boeva W planned the study; analyzed the literature; collected, analyzed and interpreted study results; wrote the manuscript; Zavyalov AN analyzed the literature; analyzed and interpreted study results; wrote the manuscript.

Compliance with ethical standards: the study was approved by the Ethics Committee of Pirogov Russian National Research Medical University (Protocol № 176 dated June 25, 2018). Informed consent was obtained from all study participants.

$\bowtie$ Correspondence should be addressed: Valentina V. Boeva Ivanovskaya, 15A, Khimki, Moscow region, 141435; boevaW@yandex.ru

Received: 09.01.2020 Accepted: 08.02.2020 Published online: 06.03.2020

DOI: $10.24075 /$ brsmu.2020.014

\section{МЕДИКАМЕНТОЗНАЯ ПРОФИЛАКТИКА САХАРНОГО ДИАБЕТА 2-ГО ТИПА У ПАЦИЕНТОВ С РАННИМИ НАРУШЕНИЯМИ УГЛЕВОДНОГО ОБМЕНА: ЭФФЕКТИВНОСТЬ И КЛИНИЧЕСКИЕ ИСХОДЫ ПРИ ДЛИТЕЛЬНОМ НАБЛЮДЕНИИ}

В. В. Боева ${ }^{1}$, А. Н. Завьялов

Федеральный клинический центр высоких медицинских технологий Федерального медико-биологического агентства России, Химки, Московская область, Россия

${ }_{2}^{2}$ Российский национальный исследовательский медицинский университет имени Н. И. Пирогова Минздрава России, Москва, Россия

Актуальность профилактики сахарного диабета (СД) 2-го типа у пациентов с предиабетом увеличивается из-за неуклонного распространения заболевания. Целью работы было оценить эффективность медикаментозной профилактики в замедлении темпов конверсии впервые выявленных нарушенной толерантности к глюкозе и нарушенной гликемии натощак (НТГ/НГН) в СД 2-го типа. Участникам исследования (1136 человек), считавшимся здоровыми после диспансеризации, повторно провели скрининг СД 2-го типа с соблюдением правил преаналитической подготовки образцов крови. Пациентам с впервые выявленными НТГ/НГН была назначена терапия метсормином и/или акарбозой, частоту конверсии НТГ/НГН в СД 2-го типа оценивали через 3 и 10 лет наблюдения. У 18,5\% ( $n=210)$ обследованных выявили различные категории нарушения углеводного обмена: СД 2-го типа - у 5,0\%, НТГ - у 5,5\%, НГН - у 8,0\%. Пациентам с впервые выявленным СД 2-го типа была назначена сахароснижающая терапия, они были исключень из последующего наблюдения. Пациентам с НТГ/НГН $(n=151)$ рекомендовали изменение образа жизни и назначили терапию метсормином (77\%) или метсормином и акарбозой (23\%). Частота конверсии СД 2-го типа в течение 3 лет активного наблюдения составила 6,8\% на фоне монотерапии метформином и 11,4\% - на фоне комбинированной терапии метформином и акарбозой. По окончании периода активного наблюдения большинство пациентов ( $n=85)$ самостоятельно прекратили терапию. Частота конверсии НТГ/НГН в СД 2-го типа через 10 лет после окончания активного наблюдения в группе без медикаментозной профилактики составила 38,8\% и 0\% - в группе принимающих метформин (p < 0,01). Показано, что длительное применение метформина предупредило развитие СД 2-го типа в отдаленном периоде у 83,3\% $(p<0,05)$.

Ключевые слова: сахарный диабет 2-го типа, нарушенная гликемия натощак, нарушенная толерантность к глюкозе, скрининг, метсормин, акарбоза, профилактика, глюкоза венозной плазмы натощак

Вклад авторов: В. В. Боева - планирование исследования, анализ литературы, сбор, анализ и интерпретация данных, подготовка черновика рукописи; А. Н. Завьялов - анализ литературы, анализ и интерпретация данных, подготовка черновика рукописи.

Соблюдение этических стандартов: исследование одобрено этическим комитетом РНИМУ имени Н. И. Пирогова (протокол № 176 от 25 июня 2018 г.) Все пациенты подписали добровольное информированное согласие на участие в исследовании.

Для корреспонденции: Валентина Владимировна Боева ул. Ивановская, д. 15А, г. Химки, Московская область, 141435; boevaW@yandex.ru

Статья получена: 09.01.2020 Статья принята к печати: 08.02.2020 Опубликована онлайн: 06.03.2020 DOI: 10.24075/vrgmu.2020.014 
Type 2 diabetes mellitus (T2DM) imposes a huge burden on society. This disease has a high, steadily rising prevalence and increases the risk of disabilities and early death in the affected individuals. It was reported that 4.1 million people in Russia were living with T2DM in 2018 [1, 2]. But according to epidemiologic surveillance, the actual number of such patients could be as high as at least 8 million. Based on extrapolation from the NATION study data, it is estimated that about 20.7 million Russians with prediabetes are undiagnosed [3] and, therefore, do not receive therapy or counseling on lifestyle modification.

Currently, it is not mandatory for healthcare providers to report patients who test positive for impaired glucose tolerance and impaired fasting glycemia (IGT/IFG); such patients are overlooked by statistical reports and are not followed up, so the actual prevalence of prediabetes remains understudied.

The primary cause of delay in the diagnosis of T2DM and detection of carbohydrate metabolism disorders in their early stages is preanalytical errors, specifically failure to comply with standard procedures for blood sample collection and handling aimed at inhibiting glycolysis in the sample. Upon sample collection, blood cells in the test tube undergo glycolysis, which causes glycose levels to decline and thus skews the result of the test. This is the reason why screening tests reveal normal glycose levels in some patients with carbohydrate metabolism disorders (18.5\% in our study); as a result, such patients are not followed up by their physicians.

Primary care physicians do not always attach due importance to IGT/IFG. They give their patients some perfunctory advice on lifestyle modification and do not prescribe any preventive pharmacotherapy; in turn, the patients do not find it necessary to follow the recommendations. Importantly, the efficacy of medication therapy in prediabetic individuals has already been confirmed by multiple studies [4-7] and meta-analyses [8].

Today, there is a need for implementing effective strategies for active case-finding of early carbohydrate metabolism disorders and their treatment. The aim of this study was to assess the long-term efficacy of preventive pharmacotherapy in delaying conversion of incident IGT/IFG to T2DM in the real clinical setting.

\section{METHODS}

\section{Study participants}

The study enrolled 1,136 adult residents of Tambov region presenting at Tambov Central Regional Hospital for an annual medical checkup under the annual health screening program in 2007. All patients were found to be healthy. Inclusion criteria: no history of carbohydrate metabolism disorders; no history of glucose-lowering therapy. Patients who screened positive for types 1 or 2 DM were excluded from the study.

\section{Study phases}

In the first phase, individuals found healthy after the annual medical checkup were screened for carbohydrate metabolism disorders; preventive pharmacotherapy was prescribed to those at risk for T2DM; the rate of IGT/IFG conversion to T2DM or normoglycemia within 3 years of follow-up was evaluated.

In the second phase, long-term outcomes were analyzed, i.e. the rate of IGT/IFG conversion to T2DM or normoglycemia within 10 years after active follow-up (Fig. 1).

The first phase is essentially a nonrandomized continuous prospective interventional study; the second phase should be regarded as a non-randomized retrospective observational controlled study.

\section{Study duration}

The active follow-up phase, which included preventive pharmacotherapy for T2DM, lasted for 3 years. Some patients continued their therapy for as long as 13 years. Its long-term efficacy was evaluated 10 years after the active follow-up phase was over.

\section{Description of medical intervention}

Disorders of carbohydrate metabolism were identified based on the screening data, including the results of the oral glucose tolerance test (OGTT). Patients with IGT/IFG received

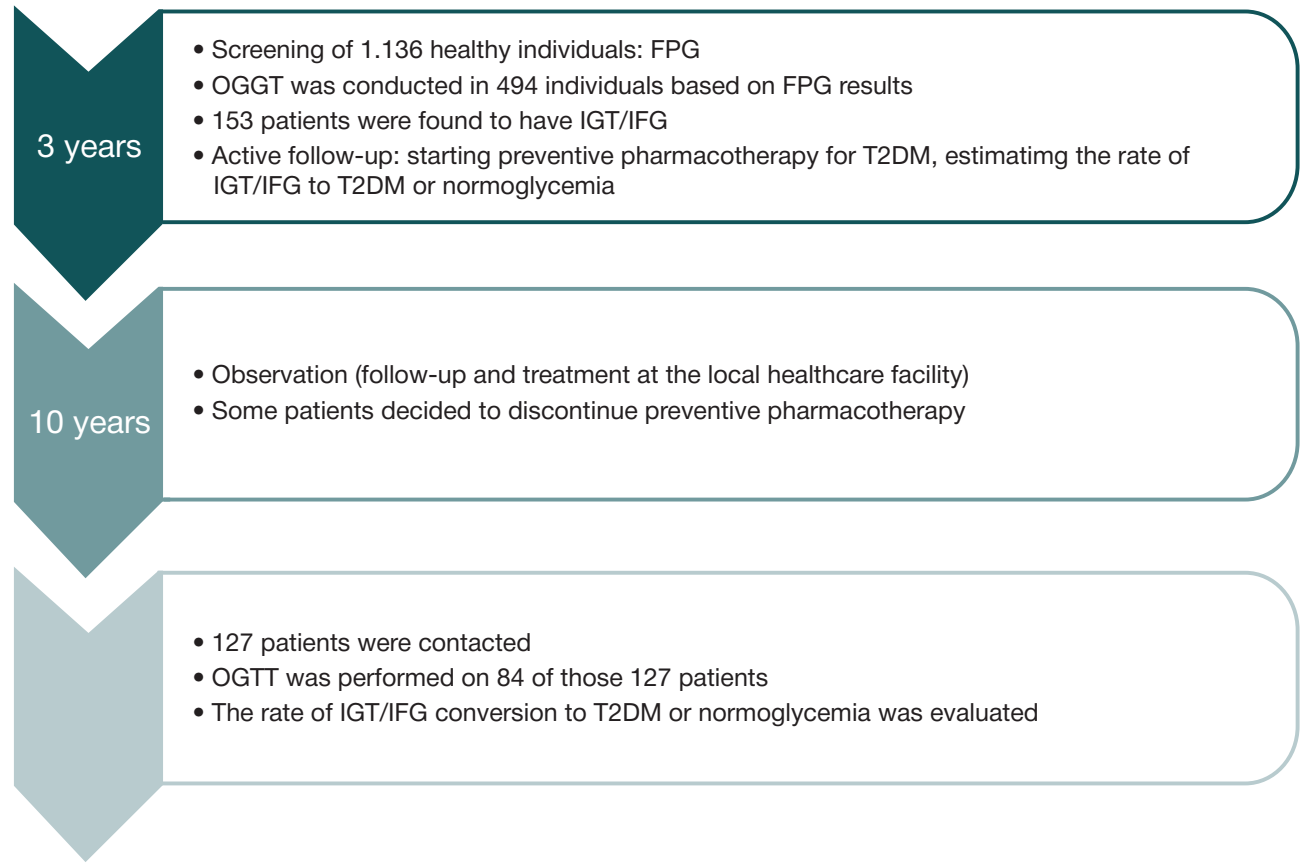

Fig. 1. A study plan. FPG — fasting plasma glucose test; OGTT - 75-gram oral glucose tolerance test 
counseling on lifestyle modification and were prescribed medication therapy. Ten years after the active follow-up phase, the patients we were able to contact were re-examined $(n=115)$. The primary focus was on the rates of IGT/IFG conversion to T2DM or normoglycemia during the active follow-up phase in the setting of preventive pharmacotherapy (3 years) and in the 10 years that had followed.

\section{Analysis of subgroups}

In the screening stage, the participants were stratified in groups by the presence of the metabolic syndrome and risk factors for T2DM.

In 10 years, the outcomes for metabolic syndrome were stratified by adherence to long-term T2DM prevention therapy. The patients available for the analysis $(n=115)$ were divided into 2 subgroups: subgroup 1 had discontinued their medications without consulting their physicians $(n=85)$, subgroup 2 had been taking metformin throughout the entire observation period $(n=30)$.

\section{Evaluation of outcomes}

Disorders of carbohydrate metabolism were diagnosed and classified following WHO guidelines published in 1999. Carbohydrate metabolism was evaluated using a conventional 2-hour 75-gram OGTT. For all samples, glucose measurements were conducted at the laboratory of Tambov Central Regional Hospital. Blood samples were collected into test tubes containing sodium fluoride. Sample preparation was performed following a standardized analytical technique.

\section{Statistical analysis}

The obtained data were processed in Statistica 6.1 (TIBCO; USA). For the analysis, we used nonparametric statistics, Pearson's $\chi^{2}$, Fisher's exact test, and Yates' correction for contingency tables. Differences were considered significant at $p<0.05$.

\section{RESULTS}

Initial screening was conducted in 1,136 individuals who denied any health complaints. The fasting plasma glucose test (FPG) revealed plasma glucose levels $\geq 7.0 \mathrm{mmol} / \mathrm{l}$ in 73 (6.4\%) individuals. The test was repeated in those patients, confirming T2DM in 37 cases. They were prescribed medication therapy and excluded from further observation. The remaining 36 patients had glycemia ranging from 6.1 to $6.9 \mathrm{mmol} / \mathrm{l}$. Those 36 patients and other 181 subjects (of 1,136 study participants) who tested positive for blood glucose in the same range underwent OGTT.

In 882 of $1,136(77.6 \%)$ subjects, FPG was below $6.1 \mathrm{mmol} / \mathrm{l}$, which $\mathrm{WHO}$ interprets as normal and does not recommend testing for DM in the short run. However, according to IDF guidelines (2005), OGTT should be performed on all patients with the metabolic syndrome (MS) whose fasting blood sugar levels are $\geq 5.6 \mathrm{mmol} / \mathrm{l}$. Of all examined study participants, 430 had FPG within the normal range (5.6-6.0 $\mathrm{mmol} / \mathrm{l})$. Of them, MS signs were detected in 169 (39.3\%) individuals, who subsequently underwent OGTT, as recommended by IDF. The rest 261 subjects had not developed a full clinical picture of MS, but 108 still had risk factors for T2DM and underwent OGTT (Fig. 2). In total, OGTT was performed on 494 people.

OGTT revealed that 20 participants (4.0\%) had T2DM, 62 participants (12.6\%) had impaired glucose tolerance, 91 participants (18.4\%) had impaired fasting glucose, and 321 participants (65.0\%) had normal glucose tolerance.

Characteristics of the patients included in the study were previously published in [9].

Of 153 prediabetic patients, $2(1.3 \%)$ had counterindications for metformin and $26(16.9 \%)$ refused to take acarbose because of its high cost. Thus, in the first year of active follow-up, there
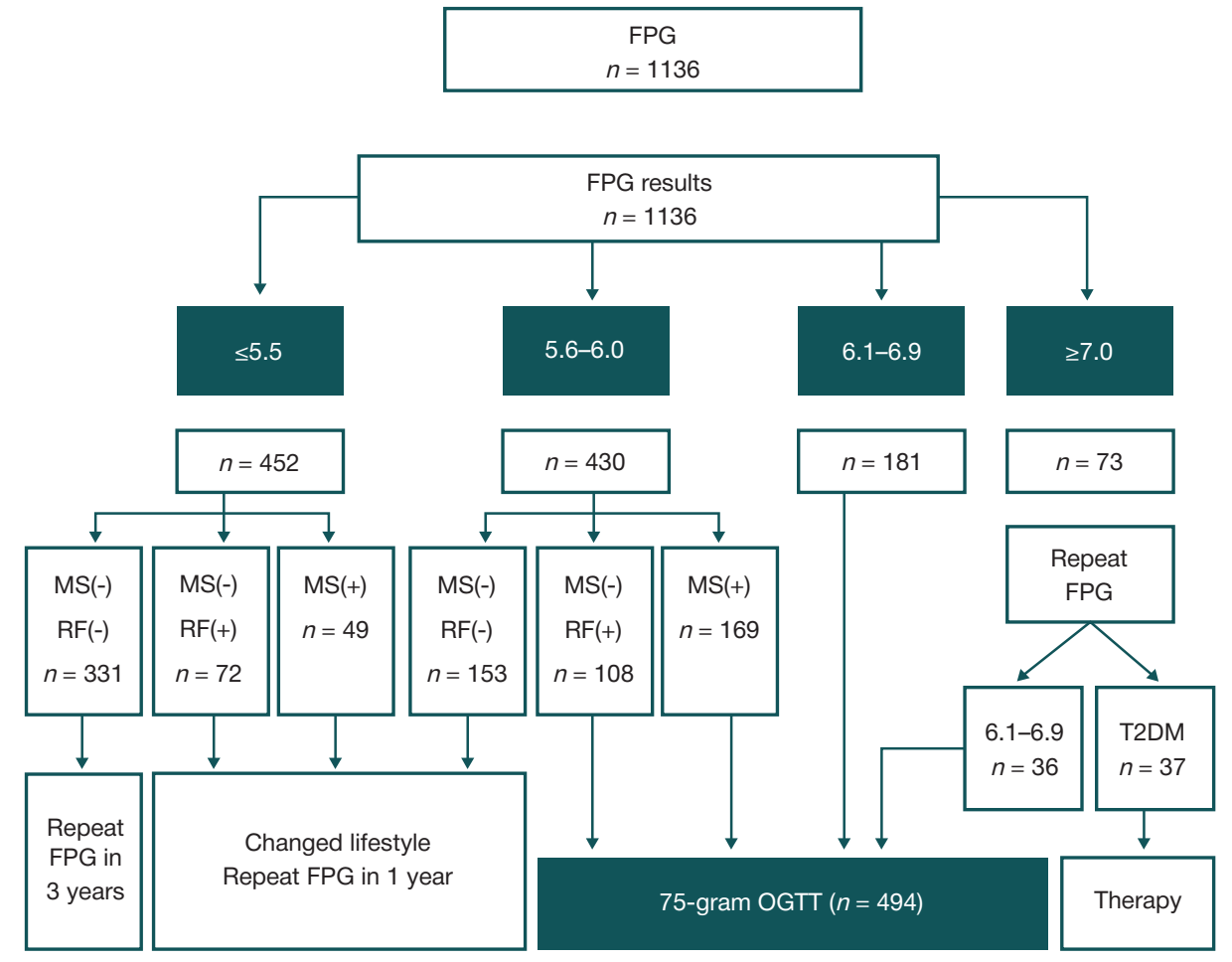

Fig. 2. Stratification of patients based on screening data for further T2DM diagnostic tests. FPG — fasting plasma glucose test; MS — metabolic syndrome; OGT — 75-gram oral glucose tolerance test; RF — risk factors for T2DM 
were 90 patients with IFG undergoing therapy with metformin (500 mg/day), 26 patients with IGT undergoing therapy with metformin (500 mg/day), 35 patients with IGT undergoing combination therapy with metformin (500 mg/day) and acarbose (titrated from $50 \mathrm{mg}$ to a maximum dose of $150 \mathrm{mg}$ following the titration scheme provided by the manufacturer). OGTT was repeated in prediabetic patients and those with normal glucose tolerance in years 2 and 3 of active follow-up. In year 3, T2DM was detected by OGTT in 4 subjects (1.4\%) with previously normal glucose tolerance; in 1 patient (1.1\%) with IFG undergoing therapy with metformin; in 2 patients $(8.7 \%)$ with IGT undergoing treatment with metformin; in 2 patients $(6.1 \%)$ with IGT undergoing treatment with metformin and acarbose. By the end of year 3, there were a total of 156 people with IGT/IFG (Fig. 3).

When the active follow-up phase, which included visits to the endocrinologist, was over, the majority of the patients discontinued their medications, in spite of having been recommended not to.

Of 156 patients with IGT/IFG, the analysis of long-term (10 years) outcomes of preventive pharmacotherapy for T2DM was done in 115 individuals. Causes for not including some patients in the analysis are shown in Fig. 4.

Of 115 people available for the analysis, 30 (26.1\%) were still taking $500 \mathrm{mg} /$ day metformin at the time of data collection for our study (2018). Eighty-five patients had chosen to terminate their treatment; of them 74 did it almost immediately after 3 years of active follow-up. Distribution of patients by type and duration of preventive pharmacotherapy after the end of the active follow-up phase is shown in Fig. 5.
Causes of poor adherence to treatment were not analyzed in detail in our study, but it should be noted that the patients reported not only health-related factors affecting their adherence but also organizational and financial issues. For example, the most common cause of non-compliance was the fact that the patients had not been followed up by their local endocrinologists and as a result had been refused prescriptions for preventive medications at their local healthcare facilities.

\section{Results of preventive pharmacotherapy}

During the active observation phase, 12 (7.9\%) of 151 prediabetic patients progressed from a carbohydrate metabolism disorder to T2DM.

In the setting of preventive therapy, OGTT was repeated in years 2 and 3 of active follow-up. In the IFG group undergoing treatment with metformin, significant positive outcomes were achieved by the patients with initial FPG of $5.6-6.0 \mathrm{mmol} / \mathrm{l}$ who were able to normalize their carbohydrate metabolism in $47.8 \%$ cases in year 2 and in $72.9 \%$ of cases in year 3 of observation $\left(\chi^{2}=6,195 ; p=0.013\right)$. Outcomes of preventive pharmacotherapy for T2DM in the IFG group achieved during the active follow-up phase are detailed in [9].

In the IGT group, the patients undergoing combination therapy with metformin and acarbose demonstrated better results than the group undergoing treatment with metformin: normal glucose tolerance was observed in the majority of patients in combination therapy in year 3 of active follow-up $\left(x^{2}=7.222 ; p=0.007\right)$. Of 115 individuals available for the analysis 10 years later, 30 (26.1\%) were still taking metformin

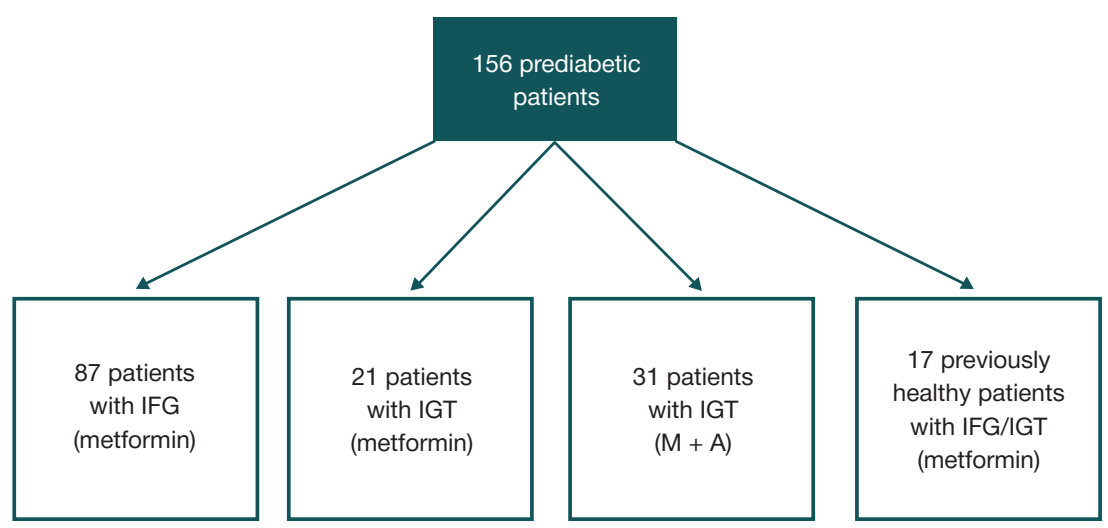

Fig. 3. Stratification of patients by the initial state of carbohydrate metabolism and prescribed therapy. M+A - therapy with metformin and acarbose

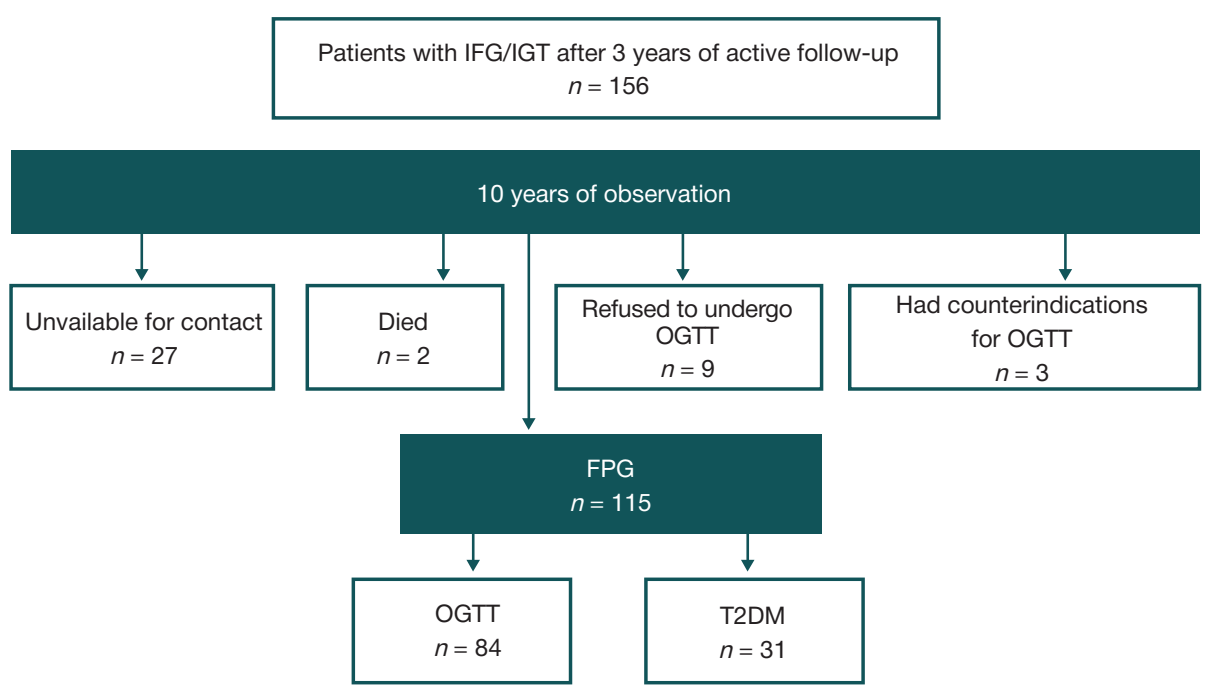

Fig. 4. Stratification of patients with IGT/IFG 10 years after the end of the active follow-up phase 


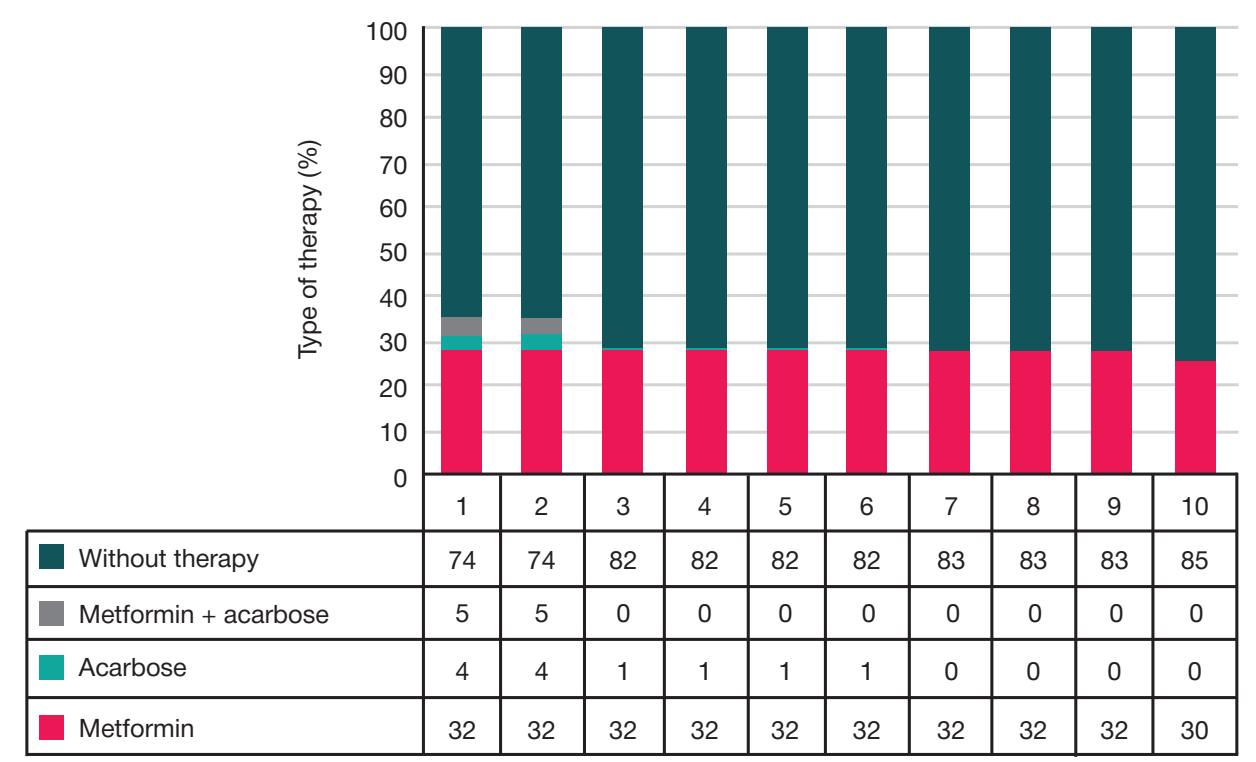

Fig. 5. Distribution of patients by type and duration of preventive pharmacotherapy after the end of the active follow-up phase (years 1 through 10)

(500 mg a day) at the time of data collection for this study (2018); the duration of acarbose intake was much shorter (Table 1).

Importantly, patients who had been taking metformin continuously did not progress to T2DM in the long run and were able to normalize their blood sugar in comparison with those who had not been taking preventive pharmacotherapy $(p<0.05)$. Ten years after the active follow-up phase, the rate of IFG/IGT conversion to T2DM was 38.8\% in the group without preventive treatment and $0 \%$ in the metformin group $(p<0.01)$.

Metformin was equally effective in preventing progression of any type of carbohydrate metabolism disorders into T2DM: no statistically significant differences in terms of outcomes were observed between the patients with IFG/IGT undergoing longterm preventive pharmacotherapy with metformin (Table 2).

Even short-term (in the active follow-up period, i.e. 3-year long) preventive pharmacotherapy against T2DM can affect the long-term outcome (10 years after the start of observation) (Table 3).

The long-term efficacy of short-term preventive pharmacotherapy turned to be higher for patients with IFG than for patients with IGT ( $p=0.012$ for achieving normal blood sugar; $p=0.004$ for progression to T2DM), which might be linked to a high rate of metformin prescription, in comparison with acarbose.

\section{Adverse effects}

No unpredicted adverse effects of preventive pharmacotherapy against T2DM were observed during the study. The analysis of other adverse events was beyond the scope of this study and was not implied by the study design.

\section{Limitations of the study}

The study had some limitations related to its design. The study was observational and the use of only routine medical interventions did not allow us to form positive and negative control groups. The patients had been undergoing diagnostic procedures and receiving medical care at their local healthcare facilities and not under the supervision of the study authors, meaning that we were unable to fully rule out the impact of external factors on the study outcomes.

\section{DISCUSSION}

The issue of adherence to preventive pharmacotherapy is closely linked to screening issues. The lack of motivation for early detection of carbohydrate metabolism disorders on part of healthcare providers leads to the lack of awareness on part of patients and results in noncompliance with prescribed medication therapy.

According to ADA standards of medical care (2019) [10, 11], the use of metformin, $\alpha$-glucosidase inhibitors, orlistat, GLP-1 agonists, and thiazolidinediones helps to reduce the incidence of T2DM, but so far, prediabetes is not an approved indication for any of these drugs. The protocol of the SiMePred study intended to evaluate the efficacy of sitagliptin (a DPP-4 inhibitor) in preventing T2DM has already been published but the results of the study are not available yet [12]. ADA experts believe that metformin should be a preferred drug for secondary prevention of T2DM. For other drugs listed above, the risks and benefits should be thoroughly considered in each individual case [10]. However, IDF guidelines formulated in 2019 recommend both metformin and acarbose (an $\alpha$-glucosidase inhibitor) for T2DM prevention in patients with early stages of carbohydrate metabolism disorders [13]. In Russia, information leaflets for metformin and acarbose list prediabetes as an indication for use $[14,15]$.

In 2005, the Diabetes mellitus state-funded program was launched in the Russian Federation under the nationwide Health project [16]. The key parameters it focused on were: life expectancy of patients with diabetes mellitus and the rate of complications in these patients, i.e. tertiary prevention. The existing electronic state registry of diabetes mellitus can also be regarded as a tool for tertiary prevention, but there is still a dearth of data on its long-term efficacy.

In our opinion, regular medical checkups and screening tests are the key measure for primary T2DM prevention [17]. Regular checkups help to identify risk factors for T2DM and subsequently take measures to reduce the contribution of modifiable risk factors to the development of the disease. Screening should be used both for regular checkups and in patients with identified risk factors. In screening tests, preanalytical errors are not rare, leading to the underdiagnosis of carbohydrate metabolism disorders. According to $\mathrm{WHO}$ report (2006), the whole blood sample collected from a patient 
Table 1. Long-term outcomes in patients who had and had not been receiving preventive pharmacotherapy

\begin{tabular}{|c|c|c|c|c|c|c|}
\hline \multirow{3}{*}{ Carbohydrate metabolism } & \multicolumn{4}{|c|}{ Number of re-examined patients $n=115$} & \multirow{3}{*}{$\chi^{2}$} & \multirow{3}{*}{$p$} \\
\hline & \multicolumn{2}{|c|}{ Preventive pharmacotherapy $n=30$} & \multicolumn{2}{|c|}{ No preventive pharmacotherapy $n=85$} & & \\
\hline & abs. & $\%$ & abs. & $\%$ & & \\
\hline Normal & 25 & 83.3 & 22 & 25.8 & 30.28 & $<0.05$ \\
\hline IFG & 1 & 3.3 & 13 & 15.2 & 3.0 & $\mathrm{SI}$ \\
\hline IGT & 4 & 13.3 & 17 & 20.0 & 0.66 & $\mathrm{SI}$ \\
\hline T2DM & 0 & 0 & 33 & 38.8 & 16.3 & $<0.01$ \\
\hline
\end{tabular}

Note: SI — statistically insignificant.

Table 2. Long-term results of OGTT in patients with different disorders of carbohydrate metabolism undergoing long-term preventive pharmacotherapy

\begin{tabular}{|c|c|c|c|c|}
\hline \multirow{2}{*}{ OGTT results in 10 years } & \multicolumn{2}{|c|}{ Initial condition of patients in the long-term pharmacotherapy group $(n=30)$} & \multirow{2}{*}{$\chi^{2}$} & \multirow{2}{*}{$p$} \\
\hline & IFG & IGT & & \\
\hline Normal & 21 & 4 & 0.250 & $>0.05$ \\
\hline IFG & 1 & 0 & 1 & $>0.05$ \\
\hline IGT & 2 & 2 & 0.169 & $>0.05$ \\
\hline T2DM & 0 & 0 & - & - \\
\hline
\end{tabular}

Table 3. Long-term results of OGTT in patients with different disorders of carbohydrate metabolism who did not have long-term preventive pharmacotherapy

\begin{tabular}{|c|c|c|c|c|}
\hline \multirow{2}{*}{ OGTT results in 10 years } & \multicolumn{2}{|c|}{$\begin{array}{c}\text { Initial condition of patients in the group without preventive } \\
\text { pharmacotherapy }(n=85)\end{array}$} & \multirow{2}{*}{$\chi^{2}$ (with Yates' correction) } \\
\cline { 2 - 4 } & IFG & IGT & 6.4 \\
\hline Normal & $17(20.0 \%)$ & $4(5.9 \%)$ & 0.012 \\
\hline IFG & $9(10.5 \%)$ & $9(10.5 \%)$ & 0.28 \\
\hline IGT & $8(9.4 \%)$ & $23(27.1 \%)$ & 0.027 \\
\hline T2DM & $10(11.8 \%)$ & 0.004 & 8.6 \\
\hline
\end{tabular}

should be placed in a blood collection tube containing a glycolysis inhibitor (collection tubes with gray caps) if immediate plasma separation is not possible. The collection tube should be kept on ice until plasma separation or the test itself. The cap color has been approved by the International Organization for Standardization (2000) [18].

Secondary prevention of T2DM includes early detection of the disease, as well as measures for slowing conversion of the initial pathology to T2DM. Secondary prevention is closely related to primary prevention: for patients with one or more risk factors for T2DM who have been covered by primary prevention, secondary prevention should consist in screening tests. Currently, there is no state-funded program on secondary prevention of T2DM (progression of prediabetes to diabetes) in Russia. Secondary prevention with pharmacotherapy has demonstrated its long-term efficacy both in this research work and in international studies $[19,20]$ and could be a cost- effective way of reducing the burden of early stage carbohydrate metabolism disorders and T2DM.

\section{CONCLUSIONS}

1. Currently, healthcare providers are not required to report patients with early disorders of carbohydrate metabolism; these patients are not followed up, which results in the underestimating the danger of IGT/IFG, delayed diagnosis of type $2 \mathrm{DM}$ and poor adherence to treatment. 2. We have demonstrated that metformin can significantly delay progression to type $2 \mathrm{DM}$ in the actual clinical setting. 3. Recommendation on active case-finding of IGT/IFG and early start of preventive pharmacotherapy should be included in the diagnostic algorithms and healthcare standards used in clinical routine. 4 . In the absence of counterindications, all patients with early disorders of carbohydrate metabolism should be prescribed long-term medication therapy with metformin.

\section{References}

1. State Diabetes Register. Professional All-Russian Resource on Diabetes Nosology under the auspices of Endocrinology Research Center. Available from: http://diaregistry.ru/content/oproekte.html\#content. Verified on May 28, 2018. Russian.

2. Dedov II, Shestakova MV, editors. Algorithms of Specialized Medical Care for Diabetes Mellitus Patients. 9th ed. Moscow, 2019. Russian.

3. Dedov II, Shestakova MV, Galstyan GR. Prevalence of Type 2 Diabetes Mellitus in Adult Russian Population (NATION study). Diabetes Mellitus. 2016; 19 (2): 104-12. Russian.

4. Ametov AS. Saharnyj diabet 2-go tipa. Problemy i reshenija. M.: GEOTAR-Media, 2017; s. 125-144. Russian.

5. Barry E. Efficacy and effectiveness of screen and treat policies in

prevention of type 2 diabetes: systematic review and meta-analysis of screening tests and interventions. BMJ. 2017 Jan 4; (356): i6538.

6. Ametov AS, Krivosheyeva AA. Prevention of type 2 diabetes mellitus. Endocrinology. 2017; (4): 14-25.

7. Chazova IE, Mychka VB, Belenkov YuN. Osnovnye rezul'taty Rossijskoj programmy 'APREL"' (jeffektivnost' primenenija akarbozy u pacientov s narushennoj tolerantnost'ju k gljukoze i arterial'noj gipertoniej). Consilium medicum. 2005; (2): 18-22. Russian.

8. Madsen KS, Chi Y, Metzendorf MI, Richter B, Hemmingsen B. Metformin for prevention or delay of type 2 diabetes mellitus and its associated complications in persons at increased risk for the development of type 2 diabetes mellitus. Cochrane Database of Systematic Reviews. 2019; (12): CD008558 
9. Demidova IYu, Boeva W. Early diagnosis and treatment of the initial stages of carbohydrate metabolism disorders. Bulletin of The Russian State Medical University. 2013; (1): 9-13.

10. Diabetes Care. 2019; 42 (Suppl. 1): 29-33.

11. Ametov AS, Krivosheyeva AA. Prospects of early pharmacological intervention at the stage of prediabetes. Endocrinology. 2018; 7 (3): 75-87.

12. Naidoo P, et al. Effect of Sitagliptin and Metformin on prediabetes progression to type 2 diabetes - a randomized, double-blind, double-arm, multicenter clinical trial: protocol for the sitagliptin and metformin in prediabetes (SiMePreD) study. JMIR Res Protoc. 2016; 5 (3): e145.

13. International Diabetes Federation. Clinical Practice Recommendations for managing Type 2 Diabetes in Primary Care, 2017.

14. Gosudarstvennyj reestr lekarstvennyh sredstv. Instrukcija po primeneniju lekarstvennogo preparata dlja medicinskogo primenenija gljukofazh, izmenenie \# 4 k P N014600/01-140812 ot 6.07.2016 g. S. 3. Data pereoformlenija: 04.04.2018 g. Russian.

15. Gosudarstvennyj reestr lekarstvennyh sredstv. Instrukcija po medicinskomu primeneniju preparata gljukobaj. Registracionnyj

\section{Литература}

1. Государственный регистр сахарного диабета Профессиональный Всероссийский ресурс по нозологиям диабета под эгидой Эндокринологического Научного Центра. Доступно по ссылке: http://diaregistry.ru/content/o-proekte. $\mathrm{html \# content} \mathrm{(проверено} \mathrm{28.05.18).}$

2. Дедов И. И., Шестакова М. В., редакторы. Алгоритмь специализированной медицинской помощи больным сахарным диабетом. 9-е изд. М., 2019.

3. Дедов И. И., Шестакова М. В., Галстян Г. Р. Распространенность сахарного диабета 2-го типа у взрослого населения России (исследование NATION). Сахарный диабет. 2016; 19 (2): 104-12.

4. Аметов А. С. Сахарный диабет 2-го типа. Проблемы и решения. M.: GEOTAR-Media, 2017; c. 125-44.

5. Barry E. Efficacy and effectiveness of screen and treat policies in prevention of type 2 diabetes: systematic review and meta-analysis of screening tests and interventions. BMJ. 2017 Jan 4; (356): i6538.

6. Аметов А. С., Кривошеева А. А. Профилактика развития сахарного диабета типа 2. Эндокринология. 2017; (4): 14-25.

7. Чазова И. Е., Мычка В. Б., Беленков Ю. Н. Основные результаты Российской программы АПРЕЛЬ (эфффективность применения акарбозы у пациентов с нарушенной толерантностью к глюкозе и артериальной гипертонией). Consilium medicum. 2005; (2): 18-22.

8. Madsen KS, Chi Y, Metzendorf MI, Richter B, Hemmingsen B. Metformin for prevention or delay of type 2 diabetes mellitus and its associated complications in persons at increased risk for the development of type 2 diabetes mellitus. Cochrane Database of Systematic Reviews. 2019; (12): CD008558

9. Демидова И. Ю., Боева В. В. Ранняя диагностика и лечение начальных стадий нарушений углеводного обмена. Вестник Российского государственного медицинского университета. 2013; (1): 9-13.

10. Diabetes Care. 2019; 42 (Suppl. 1): 29-33.

11. Аметов А. С., Кривошеева А. А. Перспективы ранней фармакологической интервенции на этапе предиабета. nomer P N012033/01 ot 24.06.2005 g. S. 2. Data pereoformlenija: 24.08.2017 g. Russian.

16. Dedov II, Shestakova MV, redaktory. The results of the implementation of the "Diabetes mellitus" subprogram of the Federal target program "Prevention and Control of Socially Significant Diseases 2007-2012". Diabetes; 2013; (2): 2-48.

17. Prikaz Minzdrava Rossii ot 3 dekabrja 2012 g. \# 1006n. Available from: https://normativ.kontur.ru/document?moduleld=1\&docume $n t l d=212999$. Russian.

18. Dolgov W, Selivanova AV, i dr. Laboratornaja diagnostika narushenij obmena uglevodov. Metabolicheskij sindrom. Saharnyj diabet. M.-Tver': Triada, 2006; 128 s. Russian.

19. Chiasson J-L, Josse RG, Gomis R, Hanefeld M, Karasik A, Laakso M, et al. Acarbose for prevention of type 2 diabetes mellitus: the STOP-NIDDM randomised trial. Lancet. 2002 Jun 15; 359 (9323): 2072-7.

20. Wenying $Y$, Lixiang $L$, Jinwu $Q$. The preventive effect of acarbose and metformin on the progression to diabetes mellitus in the IGT population: 3-year multicenter prospective study. Chin J Endocrin Metab. 2001; (17): 131-6.

Эндокринология. 2018; 7 (3): 75-87.

12. Naidoo P, et al. Effect of Sitagliptin and Metformin on prediabetes progression to type 2 diabetes - a randomized, double-blind, double-arm, multicenter clinical trial: protocol for the sitagliptin and metformin in prediabetes (SiMePreD) study. JMIR Res Protoc. 2016; 5 (3): e145

13. International Diabetes Federation. Clinical Practice Recommendations for managing Type 2 Diabetes in Primary Care, 2017.

14. Государственный реестр лекарственных средств. Инструкция по применению лекарственного препарата для медицинского применения глюкофаж, изменение № 4 к П N014600/01140812 от 6.07.2016 г. С. 3. Дата переосоормления: 04.04.2018 г.

15. Государственный реестр лекарственных средств. Инструкция по медицинскому применению препарата глюкобай. Регистрационный номер П N012033/01 от 24.06.2005 г. С. 2. Дата переоформления: 24.08.2017 г.

16. Дедов И. И., Шестакова М. В., редакторы. Результать реализации подпрограммы «Сахарный диабет» Федеральной целевой программы «Предупреждение и борьба с социально значимыми заболеваниями 2007-2012 годы». Сахарный диабет. 2013; (2): 2-48.

17. Приказ Минздрава России от 3 декабря 2012 г. № 1006н. Доступно по ссылке: https://normativ.kontur.ru/document?mod uleld=1\&documentld=212999

18. Долгов В. В., Селиванова А. В. и др. Лабораторная диагностика нарушений обмена углеводов. Метаболический синдром. Сахарный диабет. М.-Тверь: Триада, 2006; 128 с.

19. Chiasson J-L, Josse RG, Gomis R, Hanefeld M, Karasik A, Laakso M, et al. Acarbose for prevention of type 2 diabetes mellitus: the STOP-NIDDM randomised trial. Lancet. 2002 Jun 15; 359 (9323): 2072-7.

20. Wenying $Y$, Lixiang $L$, Jinwu $Q$. The preventive effect of acarbose and metformin on the progression to diabetes mellitus in the IGT population: 3-year multicenter prospective study. Chin J Endocrin Metab. 2001; (17): 131-6. 